\title{
Separation and Characterization of a Protein Antigen from Cells of Streptococcus mutans
}

\author{
By EDWARD D. ZANDERS* $†$ AND THOMAS LEHNER \\ Department of Oral Immunology and Microbiology, Guy's Hospital Medical and Dental \\ School, London SE1 9RT
}

(Received 20 May 1980)

\begin{abstract}
A protein antigen, I/II, was purified from cells and culture supernatants of Streptococcus mutans (serotype $c$ ) by solubilization in urea followed by ion exchange chromatography and gel filtration. Immunological activity was retained after further purification by preparative sodium dodecyl sulphate-polyacrylamide gel electrophoresis (SDS-PAGE). The sedimentation coefficient was estimated to be approximately $8.7 \mathrm{~S}$ by sucrose gradient centrifugation. The use of staining procedures, as well as the linear migration of this protein through different concentrations of acrylamide during SDS-PAGE, indicated that the antigen is probably not a glycoprotein. A lower molecular weight protein containing the free antigen I determinant was shown to have extensive homology with intact antigen I/II which implied that the former was a degradation product of the intact 185000 dalton antigen I/II. Antigen II, although previously defined by its resistance to proteases, could be further digested with trypsin after denaturation by SDS-PAGE. Antigen I/lI could not be correlated with a group of glucosyltransferases isolated from whole cells and culture supernatants. The cell surface location of antigen I/II was established by the lactoperoxidase-catalysed iodination of intact cells followed by protein analysis using SDS-PAGE. Previously, the potential importance of antigen I/II has been established by its immunogenicity and capacity to induce a protective immune response against dental caries.
\end{abstract}

\section{INTRODUCTION}

Effective protection against dental caries in rhesus monkeys has been consistently achieved by immunization with whole cells of Streptococcus mutans (Lehner et al., 1975, 1976). As the cells contain a large number of potential antigens, it would clearly be advantageous to separate and identify the one which induces protective immune responses to $S$. mutans. Glucosyltransferase (Guggenheim \& Newbrun, 1969) has been isolated and reported to induce protection by some authors (Hayashi et al., 1972; Taubman \& Smith, 1977) but not by others (Bowen et al., 1975; Russell et al., 1976). Among the other potential antigens, dextrans (Cisar \& Kabat, 1976), serotype-specific carbohydrates (Wetherell \& Bleiweis, 1975) and lipoteichoic acid (Markham et al., 1975) were not found to play a role in immunity against $S$. mutans when antibodies to these antigens were assayed in groups of monkeys protected and unprotected against dental caries (Russell et al., 1979).

A new series of protein antigens, I, II, III and IV, have been identified in $S$. mutans (Russell \& Lehner, 1978). Antigens I and II have been purified from culture supernatants as a single protein containing both determinants or as separated antigens present in smaller polypeptides (Russell \& Lehner, 1978; Russell et al., 1980a,b). Immunization with the intact antigen I/II induces protection against caries (Lehner et al., 1980). Antigens II and III were identified in

\footnotetext{
+ Present address: Department of Human Tumour Immunology, University College Hospital Medical School, University Street. London WC1E 6JJ.
} 
extracts of $S$. mutans (serotype $c$ ) and adsorption studies also suggested a cellular location for antigen I (Russell \& Lehner, 1978).

In this paper we report a method of extraction and purification of antigen I/II from cells of $S$. mutans as well as from the culture supernatant; in addition, these antigens have been further characterized.

\section{METHODS}

Organism. Streptococcus mutans serotype $c$ (Guy's strain), isolated from a patient at Guy's Hospital, was used throughout.

Growth conditions. For routine preparations of antigen, cultures (12l) were grown for $48 \mathrm{~h}$ in a semi-synthetic medium (Bowden et al., 1976) containing $5 \%(\mathrm{w} / \mathrm{v})$ glucose. Freeze-dried organisms were used to prepare starter cultures $(100 \mathrm{ml})$ grown overnight in Todd-Hewitt broth. These were inoculated into a 121 fermenter (Microferm, New Brunswick), after prior equilibration of the medium with $95 \% \mathrm{~N}_{2} / 5 \% \mathrm{CO}_{2}$ for $30 \mathrm{~min}$. Equilibration was continued for a further $30 \mathrm{~min}$ to minimize aeration. Large-scale cultures $(400 \mathrm{l})$ were grown at the Microbiological Research Establishment, Porton Down, and the cells were stored at $-20^{\circ} \mathrm{C}$. For biosynthetic labelling, $1 \mathrm{ml}$ cultures were grown for $60 \mathrm{~h}$ in semi-defined medium without Acidicase peptone and containing $10 \mu \mathrm{l}\left[\mathrm{U}-{ }^{14} \mathrm{C}\right]$ protein hydrolysate [specific activity $50 \mathrm{mCi}\left(\mathrm{mmol} \mathrm{C}^{-1}, 1.85 \mathrm{GBq}(\mathrm{mmol} \mathrm{C})^{-1}\right.$; The Radiochemical Centre, Amersham].

Preparation of antigen I/II. The procedure used was a modification of the method of Russell et al. (1980a). Briefly, cells were removed by centrifugation $(22000 \mathrm{~g})$ in a continuous-flow rotor (MSE) and the supernatant was made $75 \%$ saturated with respect to ammonium sulphate. After precipitation overnight at $4{ }^{\circ} \mathrm{C}$, insoluble material was recovered by continuous-flow centrifugation as above. The sediment was dissolved in $10 \mathrm{~mm}$-Tris/ $\mathrm{HCl}$ buffer pH 8.0 containing $6 \mathrm{M}$-urea (UT buffer) and dialysed for $24 \mathrm{~h}$ against water with frequent changes. The dialysate, as well as precipitated material, was made $6 \mathrm{M}$ with respect to urea by addition of crystals, and $10 \mathrm{~mm}$ with respect to Tris $/ \mathrm{HCl}$ with 0.1 vol. $100 \mathrm{mM}$-Tris $/ \mathrm{HCl}$ buffer $\mathrm{pH} 8.0$. After adjusting the $\mathrm{pH}$ if necessary, the extract was added to $200 \mathrm{ml}$ DEAE-cellulose (DE52, Whatman), equilibrated with UT buffer. After $15 \mathrm{~min}$ the slurry was centrifuged at $500 \mathrm{~g}$ for $5 \mathrm{~min}$ and the clear supernatant was discarded. Unbound material was removed by two washes with UT buffer. The cellulose was then packed into a column $(5 \times 10 \mathrm{~cm})$ and washed with UT buffer until the $A_{280}$ of the washings was zero. Antigen was eluted with $200 \mathrm{ml}$ UT buffer containing $0.15 \mathrm{M}$-sodium chloride and $12 \mathrm{ml}$ fractions were collected. After dialysis against water and lyophilization, the active fraction was dissolved in 3 to $4 \mathrm{ml} 1 \%(\mathrm{w} / \mathrm{v})$ ammonium bicarbonate and applied to a column $(1.5 \times 90 \mathrm{~cm})$ of Sepharose 6B (Pharmacia) equilibrated in the same buffer. The column was eluted at $20 \mathrm{ml} \mathrm{h}^{-1}$ and $3 \mathrm{ml}$ fractions were collected and assayed for antigen by single-radial immunodiffusion against rabbit antiserum to antigen I/II. The antigen-containing fractions were pooled and lyophilized. When further purification was desired, this material was subjected to preparative sodium dodecyl sulphate-polyacrylamide gel electrophoresis (see below).

When required, antigen I/II was prepared from cells as follows. Cells from up to 1001 culture medium were extracted with $3 \mathrm{vol}$. UT buffer and clarified at $20000 \mathrm{~g}$ for $30 \mathrm{~min}$, and the cell-free supernatant was concentrated by addition of ammonium sulphate to $40 \%$ saturation. The precipitate was then processed as above.

Sodium dodecyl sulphate-polyacrylamide gel electrophoresis (SDS-PAGE). (a) Analytical-scale electrophoresis was performed on slab gels as before (Russell et al., 1980a), with either $7.5 \%(\mathrm{w} / \mathrm{v})$ acrylamide or a 7.5 to $15 \%(\mathrm{w} / \mathrm{v})$ exponential gradient of acrylamide. Autoradiography on Kodak X-Omat $\mathrm{H}$ X-ray film was used to locate radioactive proteins.

(b) Preparative separation of proteins was effected by electrophoresis through $3 \mathrm{~mm}$ thick gels containing $5 \%$ (w/v) acrylamide. The 185000 dalton band of antigen I/II was located by parallel electrophoresis of dansylated antigen prepared by the method of Weiner et al. (1972). After visualization under ultraviolet light, the antigen-containing portion of the gel was excised using the dansylated antigen as a guide. The gel slice was homogenized with $10 \mathrm{mM}$-Tris acetate $\mathrm{pH} 8.0$ containing SDS $(0.05 \% \mathrm{w} / \mathrm{v})$ and phenylmethylsulphonyl fluoride ( $1 \mathrm{mM}$; Sigma) and incubated overnight at $37^{\circ} \mathrm{C}$ : the protein freed from the gel slice was dialysed extensively against water.

(c) To compare the relative mobilities of proteins through acrylamide gel containing different concentrations of monomer, the slab gel system described in (a) was modified as follows. An exponential gradient of 3 to $20 \%(\mathrm{w} / \mathrm{v})$ acrylamide was prepared and turned through $90^{\circ}$. Protein mixtures were then applied to the whole edge of the gel and resolved as before.

Immunological methods. Antisera to antigens I/II and II were raised in rabbits as described previously and used for antigenic analysis by immunodiffusion in agarose (Russell et al., 1980 a).

Chemical analysis. Protein was assayed by the method of Lowry using bovine serum albumin as standard. Glycoprotein staining following electrophoresis in SDS gels was performed by the method of Eckhardt et al. (1976). Neutral sugars were assayed by the phenol/sulphuric acid method (Dubois et al., 1956). 
Sedimentation analysis. Antigen I/II was sedimented through a $5 \mathrm{ml}$ gradient of 5 to $20 \%(\mathrm{w} / \mathrm{v})$ sucrose in $50 \mathrm{~mm}$-Tris/ $\mathrm{HCl}$ buffer $\mathrm{pH} 7.4$ for $23 \mathrm{~h}$ at $100000 \mathrm{~g}$ in a Beckman L5 65 ultracentrifuge at $4{ }^{\circ} \mathrm{C}$ (Martin \& Ames. 1960). ${ }^{125} \mathrm{I}$-labelled catalase, alcohol dehydrogenase and bovine serum albumin were included as internal standards. Fractions were collected from the bottom of the tube and assayed for antigen after determination of radioactivity in a Beckman Biogamma counter. The $\mathrm{S}$ value obtained was based on an assumed partial specific volume of 0.725 for the antigen (Martin \& Ames, 1960).

Determination of molecular weight. Molecular weights were estimated by SDS-PAGE as before (Russell et al." $1980 a$ ) using myosin, phosphorylase $b$, bovine serum albumin, ovalbumin. carbonic anhydrase and lysozyme as standards.

Lactoperoxidase-catalysed iodination of $S$. mutans. Cells from $2 \mathrm{ml}$ overnight cultures of $S$. mutans in Todd-Hewitt broth were washed twice in water and once in phosphate-buffered saline (PBS) containing $5 \mathrm{~mm}$-glucose. Iodination with $\mathrm{Na}^{125} \mathrm{I}(0.5 \mu \mathrm{Ci}, 18.5 \mathrm{kBq}$ : The Radiochemical Centre) was performed in $1 \mathrm{ml}$ PBS/glucose and initiated with $5 \mu$ g lactoperoxidase (EC 1.11.1.7) and 0.015 units glucose oxidase (EC 1.1.3.4) (Sigma). After $30 \mathrm{~min}$, the cells were centrifuged to form a pellet and washed four times with PBS containing $5 \mathrm{~mm}-\mathrm{Na}^{125} \mathrm{I}$. The labelled cells were then boiled in 0.1 to $0.5 \mathrm{ml}$ electrophoresis buffer and stored at $-20^{\circ} \mathrm{C}$ before use.

Peptide mapping. Antigens separated on $7.5 \%(\mathrm{w} / \mathrm{v})$ acrylamide gels were fixed and stained with Coomassie blue, followed by iodination and tryptic digestion with DPCC trypsin (Sigma), as described by Elder et al. (1977). Peptides were separated by electrophoresis on cellulose thin-layer plates (Camag, Switzerland) followed by chromatography, and were visualized by autoradiography (Seargeant \& Stinson, 1979).

Detection of glucosyltransferase activity (EC 2.4.1.5). The method of Chludzinski et al. (1974) was used with modification; $7.5 \%$ acrylamide gels containing separated proteins were incubated in $50 \mathrm{~mm}$-sodium acetate buffer containing $7 \mathrm{~mm}$-sodium fluoride, $14 \mathrm{~mm}$-sucrose and $\left[\mathrm{U}-{ }^{14} \mathrm{C} \mid\right.$ sucrose $\left(10 \mu \mathrm{Ci} \mathrm{m} l^{-1}, 370 \mathrm{kBq} \mathrm{ml}^{-1}\right.$; The Radiochemical Centre). After $3 \mathrm{~h}$ at room temperature, excess label was removed by washing the gel under running cold water for $1 \mathrm{~h}$. Enzyme activity was detected by autoradiography of the dried gel.

\section{RESULTS}

\section{Purification of antigen from cells and culture supernatants}

Antigen I/II was purified to homogeneity from cells or culture supernatants using similar methods to those described previously (Russell et al., 1980a). Several modifications were employed, however, to increase the final yield and purity of antigen and the convenience of preparation. It was found that $6 \mathrm{M}$-urea dissolved all the material generated by ammonium sulphate precipitation of culture fluid as well as removing the antigen complex from intact cells. By taking advantage of this property, no losses of antigen due to precipitation could occur. Ion exchange chromatography on DEAE-cellulose was performed by batch extraction of cell or culture extracts, followed by elution with sodium chloride. This step removed most of the coloured non-proteinaceous material which remained on the column. Gel filtration on Sepharose $6 \mathrm{~B}$ was sufficient to remove low molecular weight proteins leaving essentially pure antigen $\mathrm{I} / \mathrm{II}$ in the case of material derived from culture supernatants.

Antigen I/II was detected on SDS-PAGE as the predominant protein in culture supernatants at each stage of purification (Fig. $1 a$ ). As expected, the cell-associated antigen represented a much smaller fraction of the total protein removed by urea extraction. After gel filtration, the preparation still contained lower molecular weight proteins (Fig. $1 b$, track D), but these could be removed by preparative SDS-PAGE (Fig. $1 b$, track E) to give a single protein band. To ensure that immunological activity was retained after SDS treatment, the pure antigen and the protease-resistant component of I/II (previously identified as antigen II; Russell \& Lehner, 1978) were assayed by immunodiffusion against antiserum to I/II. A line of partial identity between antigens I/II and II was seen (Fig. 2) which showed that both the I and II determinants were still recognized by the antiserum.

The yields of antigen at each purification step, based on total protein, are shown in Table 1. It can be seen that the culture supernatant was a better source of antigen than cells from an equivalent volume of culture. The Sepharose $6 \mathrm{~B}$ fraction of cell-associated material had a lower specific activity because of the presence of contaminating proteins (see above). Neutral sugars varied from 0 to $5 \%$ of the protein content in three different preparations of Sepharose $6 \mathrm{~B}$ material. 


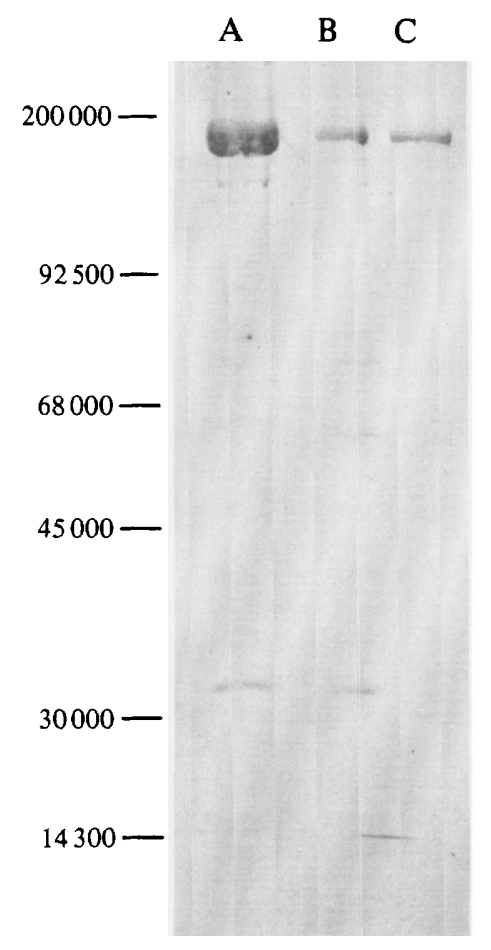

Fig. $1(a)$

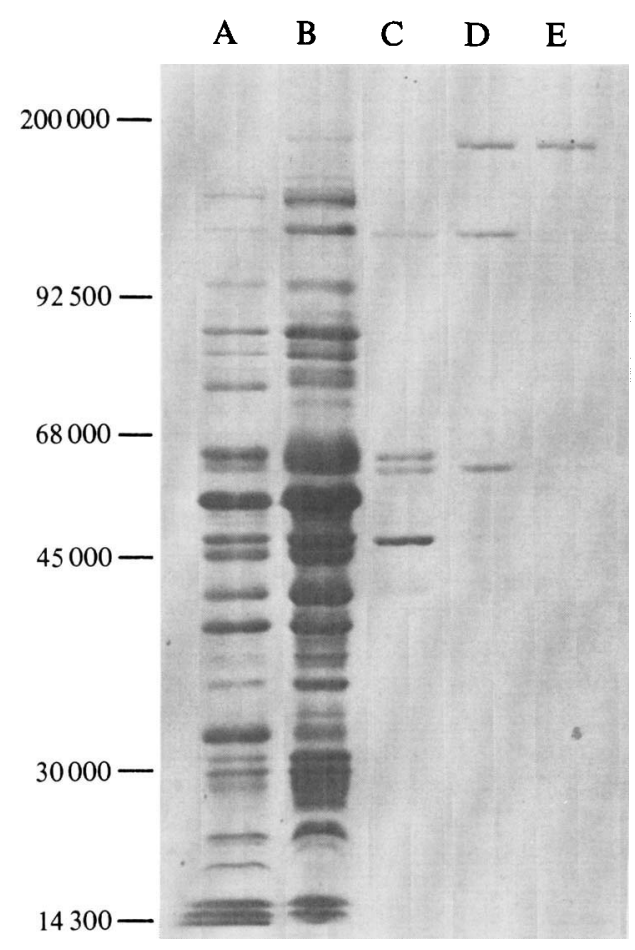

Fig. $1(b)$

Fig. 1. (a) SDS-PAGE of culture supernatant proteins: A, ammonium sulphate precipitate; B, peak from DE52 chromatography; C, peak from Sepharose 6B chromatography.

(b) SDS-PAGE of cell proteins extracted with urea: A, urea extract; B, ammonium sulphate precipitate; C, peak from DE52 chromatography; D, peak from Sepharose 6B chromatography; E, antigen I/II isolated from $5 \%(\mathrm{w} / \mathrm{v})$ preparative SDS-polyacrylamide gels and stained with Coomassie blue. Molecular weight markers were run in parallel and their positions are shown.

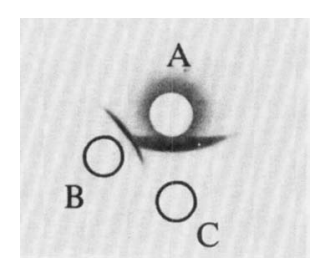

Fig. 2. Immunoprecipitation of SDS-PAGE-purified antigen I/II and antigen II with rabbit antiserum to antigen I/II: A, anti-I/II serum; $\mathrm{B}$, antigen I/II ; $\mathrm{C}$, antigen II.

\section{Physical properties of antigen $I / I I$}

The molecular weight of 185000 estimated for antigen I/II was based on SDS-PAGE (Russell et al., 1980a). It was previously noted, however, that on gel filtration, this protein consistently eluted after thyroglobulin which has a molecular weight of 660000 . This was also true for antigen prepared by the above method, even after purification by SDS-PAGE (data not shown). This finding could be due to aggregation under the buffer conditions employed, or to the fact that the antigen complex has a large frictional ratio, giving rise to an abnormally large Stokes radius on gel filtration (Siegel \& Monty, 1966; Russell et al., 1980a). To distinguish between these possibilities, the approximate sedimentation coefficient of antigen 
Table 1. Antigen yields from culture supernatants and cells

Antigen I/II was prepared from both sources as described in Methods and assayed for protein at each stage of purification to give an approximate yield.

\begin{tabular}{|c|c|c|c|}
\hline Source & Fraction & $\begin{array}{l}\text { Total protein } \\
\text { (mg) }\end{array}$ & $\begin{array}{c}\text { Yield } \\
\text { (\% initial protein) }\end{array}$ \\
\hline Culture supernatant & $\begin{array}{l}\left(\mathrm{NH}_{4}\right)_{2} \mathrm{SO}_{4} \mathrm{ppt} . \\
\text { DE52 } \\
\text { Sepharose } 6 \mathrm{~B}\end{array}$ & $\begin{array}{c}165 \cdot 0 \\
17.0 \\
1.02\end{array}$ & $\begin{array}{l}100 \\
10 \\
0.6\end{array}$ \\
\hline Cells & $\begin{array}{l}\text { Urea extract } \\
\left(\mathrm{NH}_{4}\right)_{2} \mathrm{SO}_{4} \mathrm{ppt} . \\
\text { DE52 } \\
\text { Sepharose 6B }\end{array}$ & $\begin{array}{r}875 \cdot 0 \\
375 \cdot 0 \\
16.6 \\
1.3\end{array}$ & $\begin{array}{c}100 \\
43 \\
2 \cdot 1 \\
0 \cdot 14\end{array}$ \\
\hline
\end{tabular}

I/II was determined by sucrose gradient centrifugation, with the expectation that a large frictional ratio would be reflected in an exceptionally small $\mathrm{S}$ value. The sedimentation coefficient was determined as $8.7 \mathrm{~S}$ which corresponds to a molecular weight of 156000 , using the approximation of Martin \& Ames (1960). Thus, it seemed more likely that the antigen aggregated under non-denaturing conditions. Gel filtration of Sepharose 6B-purified antigen in the presence of $\operatorname{SDS}(0.1 \%, \mathrm{w} / \mathrm{v})$ disaggregated the antigen which eluted slightly behind $\left[{ }^{14} \mathrm{C}\right]$ myosin run as an internal standard (data not shown).

\section{Chemical properties of antigen $I / I I$}

The protein nature of antigen I has been demonstrated by its sensitivity to pronase, while antigen II was identified as a pronase-resistant component. Chemical analysis of the I/II antigen described here and previously (Russell et al., 1980a) indicated that it was almost entirely protein in nature, with variable and small amounts of neutral sugars and amino sugars. The latter were probably no more than contaminants, particularly as carbohydrate staining procedures for the antigen separated by SDS-PAGE gave negative results (data not shown). In addition, the migration behaviour of antigen $\mathrm{I} / \mathrm{II}$ through different concentrations of acrylamide did not accord with the behaviour of heavily glycosylated proteins. An exponential gradient of 3 to $20 \%(\mathrm{w} / \mathrm{v})$ acrylamide was prepared and turned through $90^{\circ}$ to provide a continuous concentration gradient over a single edge; antigen applied along this edge was electrophoresed across the gel and stained. The results are shown in Fig. 3 for purified antigen and for purified antigen mixed with a whole cell extract of $S$. mutans, the latter providing a 'background' of proteins to compare with the purified antigen. While most protein bands do not cross each other at any concentration of acrylamide used, in general, modified polypeptides such as glycoproteins show altered mobility or 'cross over' at some point (Beckendorf \& Katafos, 1976). Several such proteins were detected in the mixture of purified antigen with whole cell extract. Antigen I/II, however, did not behave in this way and is therefore probably not glycosylated.

Further structural analysis involved comparison of the properties of the isolated antigens I and II with the intact I/II complex molecule by peptide mapping. Antigen I was obtained from a preparation of antigen I/II which revealed several protein bands on SDS-PAGE and in which component I was apparently dissociated (Russell et al., 1980 b). Its antigenic nature was determined by the immuno-overlay method. Antigen II, prepared by pronase digestion of I/II (Russell \& Lehner, 1978; Russell et al., 1980a), was taken as a 48000 dalton fragment resistant to further proteolysis. After electrophoresis in SDS, each determinant and the intact I/II complex molecule were radioiodinated in the stained gel slices and then digested with trypsin. The resultant peptides were separated by electrophoresis and chromatography (Fig. 4). Antigen I showed at least 20 peptides in common with the 185000 dalton antigen I/II, and in view of the variable occurrence of this component in partially purified preparations of antigen I/II, it probably represents a degradation product of the latter. It was surprising to 


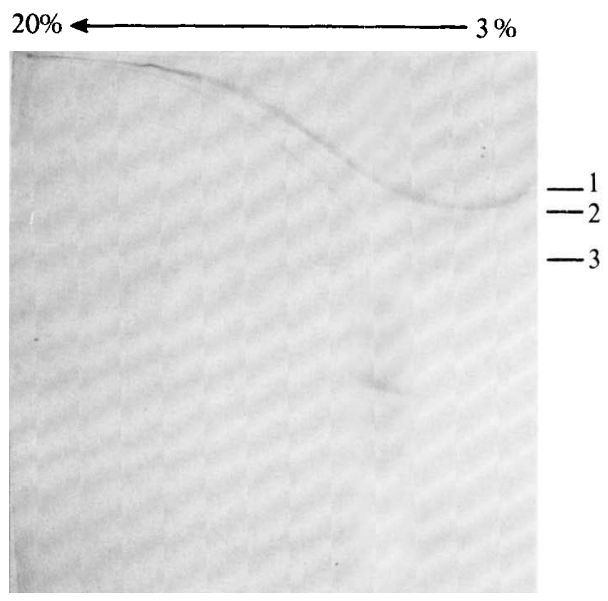

Fig. 3(a)

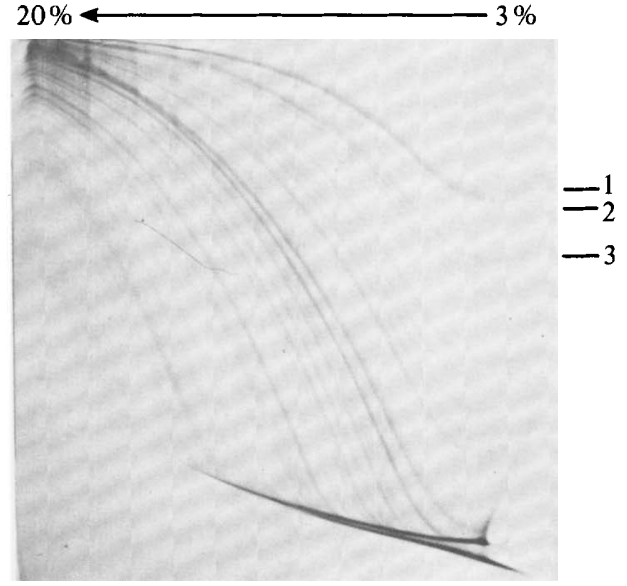

Fig. $3(b)$

Fig. 3. Electrophoresis of antigen I/II through transverse gradients of 3 to $20 \%(\mathrm{w} / \mathrm{v})$ acrylamide. (a) Culture supernatant material purified on Sepharose 6B. (b) Purified material, mixed with an SDS extract of whole cells. The numbers 1,2.3 refer to proteins detected in previous preparations of antigen I/II (Russell et al., 1980a,b).

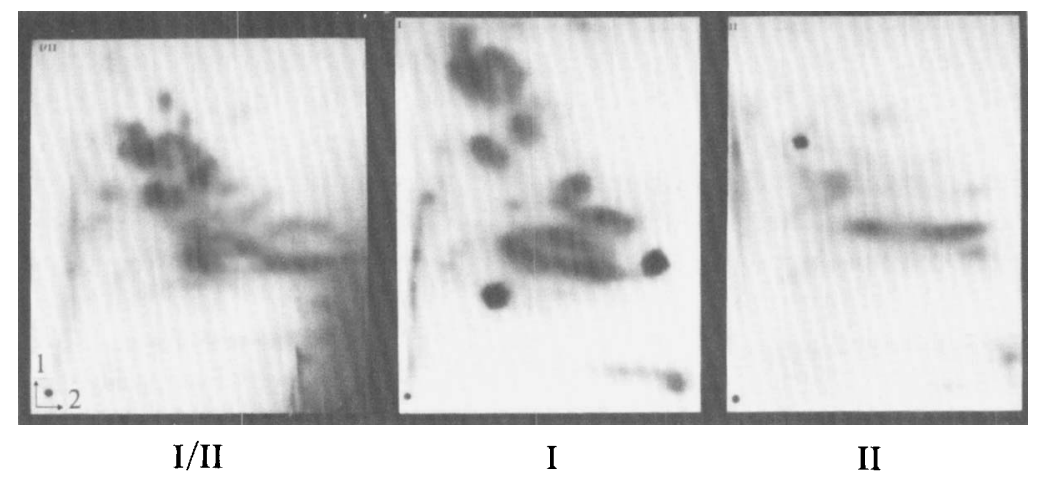

Fig. 4. Peptide maps of antigens, I, II and I/II. Antigens separated on $7.5 \%(\mathrm{w} / \mathrm{v})$ SDS gels were located by staining and iodinated in situ using the chloramine $\mathrm{T}$ method. Trypsin digestion was performed overnight and the peptides were resolved by electrophoresis (dimension 1) and chromatography (dimension 2) on cellulose thin-layer plates and detected by autoradiography.

find that antigen II could generate a significant number of peptides, as it is by definition resistant to proteolysis. It is possible that under denaturing conditions the antigen may be completely degraded. although the immunological reactivity of these tryptic peptides was not investigated.

\section{Glucosyltransferase activity in relation to antigen $I / I I$}

In their original report, Russell \& Lehner (1978) stated that glucosyltransferase activity found in hydroxylapatite fractions of culture supernatants could be separated from antigen I/II. The present work was extended to include an analysis of glucosyltransferase activity, detected after SDS-PAGE, using material from cells and culture fluids. Figure $5(a)$ shows the 




Fig. $5(a)$

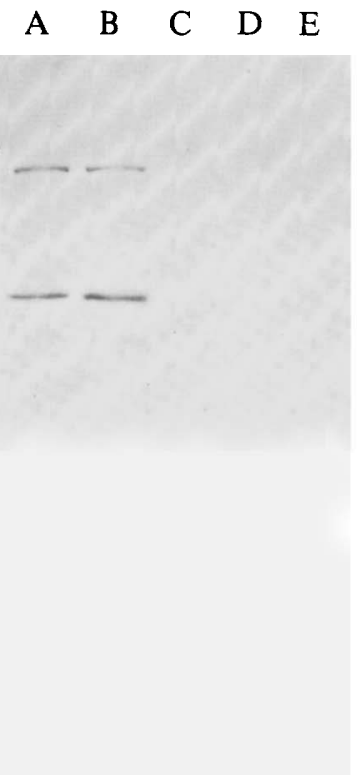

Fig. $5(b)$

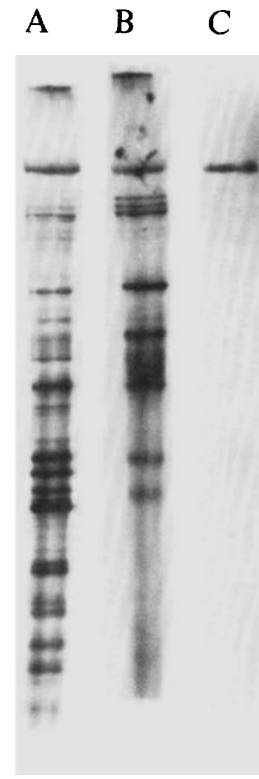

Fig. 6

Fig. 5. Glucosyltransferase activity of separated $S$. mutans proteins. Proteins were separated by SDS-PAGE, washed and incubated with $\left[{ }^{14} \mathrm{C} /\right.$ sucrose as described in Methods. (a) Culture supernatant proteins: A, ammonium sulphate precipitate: B, crude glucosyltransferase prepared by adsorption of culture fluids to hydroxylapatite (Russell \& Lehner, 1978); C, antigen I/II. (b) Cell proteins extracted with urea: samples A to E were identical to those described in Fig. 1 (b). Arrows indicate expected position of antigen I/II.

Fig. 6. Lactoperoxidase-catalysed iodination of whole cells of $S$. mutans: A, proteins from cells labelled with $\left[{ }^{14} \mathrm{Clprotein}\right.$ hydrolysate; $\mathrm{B}$, iodinated proteins; $\mathrm{C}$, immuno-overlay of iodinated proteins with antiserum to antigen I/II. All samples were extracted with $2 \%(\mathrm{w} / \mathrm{v})$ SDS and run on $7.5 \%(\mathrm{w} / \mathrm{v})$ SDS-acrylamide gels.

results of incubating separated proteins from culture supernatant, a partially purified glucosyltransferase preparation, and Sepharose $6 \mathrm{~B}$-purified antigen $\mathrm{I} / \mathrm{II}$ with $\left[{ }^{14} \mathrm{C}\right]$ sucrose. The enzyme activities present in the first two samples are clearly absent in the antigen I/II preparation; a faint band of activity present in the latter migrated separately from antigen I/II. A similar experiment was performed with urea extracts from cells and fractions obtained during subsequent purification of antigen I/II (Fig. 5b). The activity detected is clearly removed after purification on DEAE-cellulose (sample C). Although the glucosyltransferase detected probably does not represent the only sucrose-metabolizing enzyme, as many of these would be expected to be denatured under the electrophoretic conditions employed, these results collectively tend to exclude glucosyltransferase as a major component of antigen I/II.

\section{Cell surface location of antigen I/II}

In view of the finding that antigen $\mathrm{I} / \mathrm{II}$ is as effective as whole cells in inducing immunological protection against caries in the rhesus monkey (Lehner et al., 1980), it was thought that the antigen was located at or near the cell surface. The removal with urea of a limited number of proteins, including antigen I/II, from $S$. mutans provides some evidence for this. To examine this in more detail, whole cells were labelled with ${ }^{125}$ I by the lactoperoxidase 
method and disrupted by boiling in $2 \%(\mathrm{w} / \mathrm{v})$ SDS. The resulting lysate was analysed by SDS-PAGE and autoradiography (Fig. 6). For comparison, S. mutans proteins internally labelled with ${ }^{14} \mathrm{C}$-labelled amino acids were run in parallel (track A). Several major proteins were iodinated (track B) and because lactoperoxidase is unable to penetrate the cell wall, these were assumed to be located at the cell surface. Antigen I/II was identified by its relative mobility and the formation of an immunoprecipitate with rabbit antisera to I/II in the agarose overlay technique (track C) (Russell et al., 1980a). Preliminary peptide mapping studies have indicated that antigen I/II labelled in this manner contains several peptides derived from both antigens I and II. If this were the case, it is unlikely that a significant proportion of the molecule is buried within the cell wall or membrane. The other protein bands iodinated at the cell surface have not been identified.

\section{DISCUSSION}

Antigens I and II were previously extracted from the culture supernatants of S. mutans serotype $c$, although their presence in the cells of this organism and other serotypes was recognized (Russell \& Lehner, 1978; Russell et al., 1980a, b). We have now been able to prepare these antigens from cells of serotype $c$ bacteria. A comparison of antigen I/II from cells and from culture fluids clearly established their identity. Both showed two antigenic determinants on precipitation with antisera to the two components and their relative mobilities on SDS-PAGE were identical. It would be reasonable to assume that the antigen is shed from the cell into the culture medium during growth. We have consistently found substantially higher amounts of antigen in the medium after the cultures have entered the stationary phase of growth; thus, the bulk of cell-associated antigen is possibly released passively by cell lysis, although firm evidence for this is not available. Whereas urea may be used to extract antigen from cells, for preparative purposes it seems more efficient to use culture supernatants as the starting material

Antigen I/II is located at the cell surface as shown by lactoperoxidase-catalysed iodination. This is consistent with the findings using an immunofluorescent technique (Lehner et al., 1980). The presence of this antigen at the cell surface accounts for the high immunogenicity of this material whether in the whole cells or in a purified form. One injection of $1 \mathrm{mg}$ antigen I/II in Freund's incomplete adjuvant induces IgG class antibodies with a high titre and affinity (Lehner et al., 1980; Smith \& Lehner, 1981). Furthermore, small amounts $(0.01 \mu \mathrm{g})$ of this material can induce $\mathrm{T}$ cell helper activity which potentiates $\mathrm{B}$ cell antibody formation (Lamb et al., 1980).

In addition to the protein antigens identified in culture supernatants of $S$. mutans (Russell \& Lehner, 1978), two of which have also been extracted from cells, at least four other protein antigens have been reported. Recently, a protein antigen, designated $\mathrm{B}$, has been described (Russell, R. R. B., 1979) which has a similar molecular weight (190000) to antigen I/II (185000) but differs in its $\mathrm{pI}(5.4)$ and pronase sensitivity and in that it appears to have only one antigenic component. It remains to be determined to what extent, if any, antigen $B$ (Russell, R. R. B., 1979) compares with antigen I/II prepared from culture supernatant (Russell \& Lehner, 1978; Russell et al., 1980 a) and that from cells described in this paper. A number of glucosyltransferases have been described (Guggenheim \& Newbrun, 1969) and also a dextran-binding protein (McCabe et al., 1977). The relevance of these proteins to protection against dental caries has not been tested, however, with the exception of glucosyltransferase which was effective in some experiments (Taubman \& Smith, 1977) but not others (Bowen et al., 1975; Lehner et al., 1975). The protein antigen I/II purified to homogeneity from cells and culture supernatants induces protection against dental caries (Lehner et al., 1980). It was administered in a dose of $1 \mathrm{mg}$ in adjuvant subcutaneously without any observable side effects. As this experiment was designed so as to be relevant to immunization in man, antigen I/II evidently has potential importance as a protective antigen. 


\section{REFERENCES}

BECKENDORF, S. K. \& KatAFos, F. C. (1976). Differentiation in the salivary glands of Drosophila melanogaster: characterization of the glue proteins and their developmental appearance. Cell 9, 365373.

Bowden. G. H., Hardie. J. M. \& Fillery. E. D. (1976). Antigens from actinomyces species and their value in identification. Journal of Dental Research 55. Special Issue A, A 192-A204.

Bowen, W. H., Cohen, B., Cole, M. F. \& Colman, G. (1975). Immunisation against dental caries. British Dental Journal 139, 45-48.

Chludzinski, A. M., Germaine, G. R. \& Schactele, G. F. (1974). Purification and properties of dextransucrase from Streptococcus mutans. Journal of Bacteriology 118, 1-7.

Cisar, J. O. \& Kabat, E. A. (1976). The immunology of dextrans. In Immunological Aspects of Dental Caries, pp. 61-80. Edited by W. H. Bowen. R. J. Genco \& T. C. O’Brien. Washington: Information Retrieval Inc.

Dubois, M., Gilles, K. A., Hamilton, J. K., Rebers, P. A. \& SмIтH, F. (1956). Colorimetric method for determination of sugars and related substances. Analytical Chemistry 28, 350-356.

ECKhaRdt, A. E.. HAyes, C. E. \& Goldstein. I. J. (1976). A sensitive fluorescent method for the detection of glycoproteins in polyacrylamide gels. Analytical Biochemistry 73, 192-197.

Elder, J. H., Gautsch, J. W., Jensen, F. C., LeRner, R. A., Hartley, J. W. \& Rowe, W. P. (1977). Biochemical evidence that MCF murine leukemia viruses are envelope (env) gene recombinants. Journal of Biological Chemistry 74, 46264680.

GugGenheim. B. \& Newbrun. E. (1969). Extracellular glucosyltransferase activity on an HS strain of Streptococcus mutans. Helvetica odontologica acta 13. 84-97.

Hayashi, J. A.. Shklair, I. L. \& BahN, A. N. (1972). Immunization with dextransucrases and glycosidic hydrolases. Journal of Dental Research 51(2), Supplement, 436-442.

LAmb, J. R., Kontiainen, S. \& LehneR, T. (1980). A comparative investigation of the generation of specific $T$ cell helper function induced by Streptococcus mutans in monkeys and mice. Journal of Immunology 124, 2384-2389.

Lehner, T., Challacombe, S. J. \& Caldwell, J. (1975). Immunological and bacteriological basis for vaccination against dental caries in rhesus monkeys. Nature, London 254, 517-520.

Lehner, T., Challacombe, S. J. \& Caldwell, J. (1976). Cellular and humoral immune response in vaccination against dental caries in monkeys Nature, London 264, 69-71.

Lehner, T., Russell, M. W. \& Caldwell, J. (1980). Immunisation with a purified protein from Streptococcus mutans against dental caries in Rhesus monkeys. Lancet 1, 995-996.

McCAвE, M. M., Hamelik, R. M. \& Smith, E. E. (1977). Purification of dextran binding protein from cariogenic Streptococcus mutans. Biochemical and
Biophysical Research Communications 78, 273278.

MarkhaM, J. L., KnOX. K. W.. Wicken, A. J. \& HEWETT, M. J. (1975). Formation of extracellular lipoteichoic acid by oral streptococci and lactobacilli. Infection and Immunity 12, 378-386.

MARTIN, R. G. \& AmEs, B. N. (1960). A method for determining the sedimentation behavior of enzymes: application to protein mixtures. Journal of Biological Chemistry 236, 1372-1379.

Russell, M. W. \& LeHner, T. (1978). Characterization of antigens extracted from cells and culture fluids of Streptococcus mutans serotype c. Archives of Oral Biology 23, 7-15.

Russell, M. W., Challacombe, S. J. \& Lehner, T. (1976). Serum glucosyltransferase inhibiting antibodies and dental caries in rhesus monkeys immunized against Streptococcus mutans. Immunology 30 , 619-627.

Russell, M. W., Caldwell, J. \& Lehner, T. (1979). Antibody responses to Streptococcus mutans antigens during immunization against dental caries. In Pathogenic Streptococci, pp. 217-218. Edited by M. T. Parker. Chertsey, Surrey: Reedbooks.

Russell, M. W., Bergmeier, L., Zanders, E. D. \& LEHNER, T. $(1980 a)$. Protein antigens of Streptococcus mutans: purification and properties of a double antigen and its protease resistant component. Infection and Immunity 28, 486-493.

Russell, M. W., Zanders, E. D., Bergmeier, L. \& LEHNER, T. $(1980 \mathrm{~b})$. Affinity purification and characterization of the protease susceptible antigen I of Streptococcus mutans. Infection and Immunity 29, 999-1006.

Russell, R. R. B. (1979). Wall-associated protein antigens of Streptococcus mutans. Journal of General Microbiology 114. 109-115.

Seargeant, L. E. \& Stinson, R. A. (1979). Evidence that three structural genes code for human alkaline phosphatase. Nature, London 281, 152-154.

SiEgel, L. M. \& MonTy, K. J. (1966). Determinations of molecular weights and frictional ratios of proteins in impure systems by use of gel filtration and density gradient centrifugation. Application to crude preparations of sulfite and hydroxylamine reductases. Biochimica et biophysica acta 112, 346-362.

Smith, R. \& LehNeR, T. (1981). A solid phase radioimmunoassay for specific antibodies to a purified protein of Streptococcus mutans. Journal of Dental Research (in the Press).

Taubman, M. A. \& SMith, D. J. (1977). Effects of local immunization with glucosyltransferase fractions from Streptococcus mutans on dental caries in rats and hamsters. Journal of Immunology 118 , $710-720$

Weiner, A. M., Platt, T. \& Weber, K. (1972). Amino terminal sequence analysis of proteins purified on a nanomole scale by gel electrophoresis. Journal of Biological Chemistry 247, 3242-3251.

Wetherell, J. R. \& Bleiweis, A. S. (1975). Antigens of Streptococcus mutans. III. Characterization of a polysaccharide antigen from walls of strain GS-5. Infection and Immunity 12, 1341-1348. 